\title{
MISCELLANEOUS.
}

\section{Researches upon the Defensive Glands of Bombardier Beetles.} By Fr. Dierckx.

IN a note published in the 'Comptes Rendus' of January 23, 1899, Mons. L. Bordas describes the anal gland of Carabus nemoralis, Illig. For a long time past we have studied the same organ in a considerable number of species, and we have arrived at results that do not always agree with those of M. Bordas. We have therefore thought $t$ useful to introduce a few critical observations into the description of an allied type, which in many respects is more interesting.

Since the species of Brachynus present a strong contrast to the rest of the Carabidæ, owing to the faculty which the various species possess of projecting, with crepitation and the formation of a conspicuous puff of vapour, the secretory product of their anal glands, let us seek to determine the conditions of this phenomenon.

I. Anatomy.-In Brachynus crepitans, L., the glandular apparatus is double and situated, as in the other Carabidæ, on both sides of the rectum. Each element is composed of a secreting portion, a collecting-duct, and a reservoir.

A. Secretory lobes.-Each cylindrical lobe of the aciniform gland is traversed by a duct with a cuticular wall strewn with little nuclei. Between this axial duct and the enveloping propria lie the active cells, each enclosing, besides the nucleus, a radiated pyriform vesicle, drained by a canaliculate filament. M. Bordas does not mention this intracellular vesicle in the case of Carabus nemoralis; we have observed it in all the species examined, with modifications interesting from the point of view of taxonomy.

B. Collecting-duct.-This is from 25 to 30 millim. in length in the case of Brachynus, and is constituted by two tubes which fit one into the other, the innermost of which is kept wide open by means of a series of hyaline cuticular disks, which are set more or less close together from one end of the duct to the other. Excluding the propria, there is only a single layer of cells; the axial tube which is enclosed therefore results cytologically from the cells of the outer wall, where the nuclei are always ensconced. The species of Carabus have the disks merely outlined, and the tube does not possess a double wall. In Panagous the outline of the disks has entirely disappeared. From this simpler condition to the more complex forms the differentiation of the cells varies greatly; but in no species have we met with a wall consisting of several layers of cells. We do not know how M. Bordas was able to detect in this structure, in the case of Carabus nemoralis, two muscular coats and an internal epithelium with flattened cells.

C. Reservoir.-This is in the shape of a wallet with the convex side towards the axis of the body. The collecting-duct opens in the 
concave depression. The anterior sac corresponds to the ovoid reservoir in the other genera; the posterior sac is the homologue of their cylindrical ejaculatory duct. It opens by two pores at the tip of the pygidium, a little in front of the anus. In Carabus the discharging-pores are about 2 millim. from the median line and about 1 millim. behind the posterior stigmata. According to M. Bordas the gland would open into the cloaca, and its action would imply a mechanism of an extremely complex character.

II. Physionogy.-The fluid secreted.-This is colourless, limpid, with a slight but characteristic odour, and much less acid than the product of Carabus. Its most remarkable property is its very great volatility. It boils, according to our observations, at a temperature of about $+9^{\circ}$ C., under a pressure of 760 millim.

Anatomical proofs.-(1) The feebleness of the muscular wall of the reservoir in comparison with the mechanical effects produced ; $(2)$ the existence in the reservoir of transverse stays, destined without doubt to counterbalance the internal pressures; $(3)$ the enlargement of the ejaculatory duct near the external aperture of the gland, in view of the abrupt expulsion of the glandular fluid; (4) the presence-in the discharging-pores of chitinous pieces bristling: with hairs, and capable of performing the function of a pulverizer.

Physiological proofs.-(1) The explosive nature of the crepitation ; (2) the effervescence, which results at the expense of the glandular fluid on dissection under water or on slides as soon as the organ is injured, but only at a temperature higher than $+8^{\circ} \mathrm{C}$.; (3) the crepitation that takes place upon the dead insect when one opens the discharging-pores.

III. Mode of Action.-The insect, on being alarmed, protrudes its hind quarters (dégaine l'arrière-train); if the obturator sphincters then relax, the liquid contents of the reservoir escape under pressure, and the jet is divided up by the chitinous combs of the orifice. It is, on a small scale, the action of a bomb charged with liquefied carbonic acid gas.

In spite of the perfect limpidity of the glandular secretion, the discharge leaves a fixed yellowish residue, already observed by Dufour. This is shown by the microscope to be identical with the contents of the rectum. At the moment of danger the insect bends its abdomen downwards; this curvature brings the dischargingpores behind the anal sphincter. When, in this attitude, the volatile liquid is liberated, while the rectum empties itself, the squib will go off beneath the body, from behind forwards, reducing to powder the ejected excrement-a case-shot of a new kind, well calculated to disconcert the most audacious and best-armed aggressor *.Comptes Rendus, t. cxxviii. no. 10 (March 6, 1899), pp.622-624.

* Fxtracted from an "Étude comparée des Glandes pygidiennes chez les Carabides et les Dytiscides," carried out under the direction of Prof. Gilson at the Carnoy Institute at Louvain. 


\section{$2 \mathrm{BHL}$ Biodiversity Heritage Library}

Dierckx, Fr. 1899. "Researches upon the defensive glands of Bombardier beetles." The Annals and magazine of natural history; zoology, botany, and geology 4, 315-316. https://doi.org/10.1080/00222939908678205.

View This Item Online: https://www.biodiversitylibrary.org/item/81048

DOI: https://doi.org/10.1080/00222939908678205

Permalink: https://www.biodiversitylibrary.org/partpdf/62894

\section{Holding Institution}

Smithsonian Libraries

\section{Sponsored by}

Smithsonian

\section{Copyright \& Reuse}

Copyright Status: Public domain. The BHL considers that this work is no longer under copyright protection.

This document was created from content at the Biodiversity Heritage Library, the world's largest open access digital library for biodiversity literature and archives. Visit BHL at https://www.biodiversitylibrary.org. 